\title{
Diagnostic Accuracy of CYFRA21-1 in the Differential Diagnosis of Pleural Effusions
}

\author{
JAUME TRAPÉ 1,2, FRANCESC SANT $^{2,3}$, JESUS MONTESINOS ${ }^{4}$, ANNA ARNAU ${ }^{5}$, MARIA SALA ${ }^{1}$, \\ OSCAR BERNADICH ${ }^{6}$, ESPERANZA MARTÍN ${ }^{6}$, DAMIA PERICH ${ }^{6}$, JOAN LOPEZ ${ }^{1}$, SANDRA ROS ${ }^{6}$, \\ ENRIQUE ESTEVE-VALVERDE ${ }^{7}$, RAFAEL PÉREZ $^{7}$, CAROLINA GONZÁLEZ-FERNÁNDEZ $^{1}$, \\ JORDI ALIGUE ${ }^{7}$, SILVIA CATOT ${ }^{4}$, MONTSERRAT DOMENECH ${ }^{4}$, DOMINGO RUIZ ${ }^{7}$, \\ MARIONA BONET ${ }^{7}$, RAFAEL MOLINA ${ }^{8}$ and JOSEP ORDEIG $^{7}$ \\ ${ }^{1}$ Department of Laboratory Medicine, Althaia Xarxa Assistencial Universitària de Manresa, Manresa, Spain; \\ ${ }^{2}$ Faculty of Medicine, University of Vic - Central University of Catalonia, Barcelona, Spain; \\ ${ }^{3}$ Department of Pathology, Althaia Xarxa Assistencial Universitària de Manresa, Manresa, Spain; \\ ${ }^{4}$ Department of Oncology, Althaia Xarxa Assistencial Universitària de Manresa, Manresa, Spain; \\ ${ }^{5}$ Clinical Research Unit, Althaia Xarxa Assistencial Universitària de Manresa, Manresa, Spain; \\ ${ }^{6}$ Department of Pulmonary Diseases, Althaia Xarxa Assistencial Universitària de Manresa, Manresa, Spain; \\ ${ }^{7}$ Department Internal Medicine, Althaia Xarxa Assistencial Universitària de Manresa, Manresa, Spain; \\ ${ }^{8}$ Department of Clinical Biochemistry, Hospital Clínic, Barcelona, Spain
}

\begin{abstract}
Background/Aim: Approximately 20\% of pleural effusions are associated with cancer; about $50 \%$ require invasive procedures to perform diagnosis. Determination of the concentration of soluble cytokeratin 19-fragments (CYFRA211) may help identify patients with malignant effusions. However, pathologies other than cancer can increase its concentration. The identification of these possible false positives with routine tests $C R P, A D A, \%$ polymorphonuclear cells $(P N)$ may improve diagnostic accuracy. This study aimed to determine the diagnostic accuracy of CYFRA21-1 in the detection of malignant pleural effusions and the possible false positives. Materials and Methods: Analysis of CYFRA21-1, adenosine deaminase ( $A D A), C$-reactive protein $(C R P)$, and the percentage of polymorphonuclear leukocytes (PN\%) in the fluid from 643 consecutive undiagnosed pleural effusions was performed. Results: CYFRA21-1 showed $38.7 \%$ sensitivity and 97.3\% specificity at $175 \mathrm{ng} / \mathrm{ml}$ cut-off. Effusions not suspicious of a false-positive showed $39.0 \%$ sensitivity and $98.2 \%$ specificity, while effusions suspicious of false positive showed lower sensitivity (36.4\%) and specificity (95.0\%). Conclusion: The diagnostic accuracy of CYFRA21-1 in pleural effusions
\end{abstract}

Correspondence to: Jaume Trapé, Ph.D., Department of Laboratory Medicine, Althaia, Xarxa Assistencial Universitària de Manresa, F.P., Dr Joan Soler 1-3, 08243 Manresa, Catalonia, Spain. Tel: +34 938742112, e-mail jtrape@althaia.cat

Key Words: CYFRA 21-1, pleural effusion, differential diagnosis, malignant effusion. can be improved by classification according to the possibility of false positives.

Pleural effusions can be caused by a wide variety of diseases. Among them, cancer is one of the most frequent; with rates between $15 \%$ and $27 \%(1,2)$. Differential diagnosis of pleural effusions is not easy. Cytology is the gold standard test for ruling out cancer, but its sensitivity is only moderate (between $45 \%$ and $70 \%)(2,3)$. This means that more invasive tests are sometimes necessary, increasing morbidity and raising the economic cost.

Soluble cytokeratin 19-fragments (CYFRA21-1) have been evaluated in the differential diagnosis of cancer in pleural effusions. The results vary widely from study to study; the specificity ranges between $7 \%$ and $100 \%$ and the sensitivity between $25 \%$ and $90 \%$, using discriminant values between 3.3 $\mathrm{ng} / \mathrm{ml}$ and $175 \mathrm{ng} / \mathrm{ml}$ (4-10). Most studies applying highly discriminant values $(55-175 \mathrm{ng} / \mathrm{ml})$ obtained sensitivities between $24 \%$ and $70 \%$ and specificities above $95 \%(6,10-13)$. However, in diseases such as tuberculosis, empyema and parapneumonic effusions, as well as in inflammatory processes of the surrounding tissues, high concentrations of this tumor marker can be found in the pleural fluid $(11,14,15)$. Some biomarkers suggest a benign diagnosis: examples are adenosine deaminase (ADA) in tuberculosis and empyema, white blood cell count and the percentage of polymorphonuclear leukocytes (PN\%) in empyema and complicated parapneumonic effusions, and C-reactive protein (CRP) in all three of the above conditions, and in the process of necrosis or inflammation of the surrounding tissues. 
Table I. Etiology of the effusions included in the study.

\begin{tabular}{|c|c|c|c|}
\hline & $\begin{array}{c}\text { Group A } \\
(\mathrm{n}=502)(78.1 \%)\end{array}$ & $\begin{array}{c}\text { Group B } \\
(\mathrm{n}=141)(21.9 \%)\end{array}$ & $\begin{array}{l}\text { All effusions } \\
\quad(\mathrm{n}=643)\end{array}$ \\
\hline Neoplastic & $163(88.1 \%)$ & $22(11.9 \%)$ & 185 \\
\hline Lung cancer & $70(92.1 \%)$ & $6(7.9 \%)$ & 76 \\
\hline Breast cancer & $22(91.7 \%)$ & $2(8.3 \%)$ & 24 \\
\hline Mesothelioma & $18(81.8 \%)$ & $4(18.2 \%)$ & 22 \\
\hline CUP 1 & $19(90.5 \%)$ & $2(9.5 \%)$ & 21 \\
\hline Ovarian cancer & $9(90.0 \%)$ & $1(10.0 \%)$ & 10 \\
\hline Lymphoma & $5(50.0 \%)$ & $5(50.0 \%)$ & 10 \\
\hline Bladder cancer & $5(100.0 \%)$ & $0(0.0 \%)$ & 5 \\
\hline Others $^{2}$ & $15(88.2 \%)$ & $2(11.8 \%)$ & 17 \\
\hline Cardiogenic & $109(87.2 \%)$ & $16(12.8 \%)$ & 125 \\
\hline \multicolumn{4}{|l|}{ Parapneumonic } \\
\hline Non-complicated & $44(89.8 \%)$ & $5(10.2 \%)$ & 49 \\
\hline Complicated & $5(16.1 \%)$ & $26(83.9 \%)$ & 31 \\
\hline Empyema & $2(8.3 \%)$ & $22(91.7 \%)$ & 24 \\
\hline Tuberculosis & $0(0.0 \%)$ & $22(100 \%)$ & 22 \\
\hline Rheumatoid arthritis & $3(33.3 \%)$ & $6(66.7 \%)$ & 9 \\
\hline Cirrhosis & $15(100.0 \%)$ & $0(0.0 \%)$ & 15 \\
\hline Paraneoplastic & $44(81.5 \%)$ & $10(18.5 \%)$ & 54 \\
\hline $\mathrm{PTE}^{3}$ & $10(90.9 \%)$ & $1(9.1 \%)$ & 11 \\
\hline Post traumatic & $13(100.0 \%)$ & $0(0.0 \%)$ & 13 \\
\hline Pneumonitis & $6(54,5 \%)$ & $5(45.5 \%)$ & 11 \\
\hline $\begin{array}{l}\text { Asbestosis, nephrotic syndrome, ARDS }{ }^{4} \text {, } \\
\text { pancreatitis, hypothyroidism, uremia, others }\end{array}$ & $88(93.6 \%)$ & $6(6.4 \%)$ & 94 \\
\hline
\end{tabular}

${ }^{1}$ Cancer of known primary site; ${ }^{2}$ Pancreatic, gastric, colon, endometrial, cervix, sarcoma, multiple myeloma, melanoma, cholangiocarcinoma, hypernephroma. ${ }^{3}$ pulmonary thromboembolism; ${ }^{4}$ adult respiratory distress syndrome.

In a previous work by our group, classifying the effusions with the aid of these biomarkers indicating a benign status, enabled us to differentiate between two groups of patients, presenting pleural effusions with regard to cancer prevalence. Those that were negative for all the benign biomarkers presented higher cancer prevalence and greater diagnostic sensitivity of malignancy (16).

The aim of this study was to determine the diagnostic accuracy of CYFRA21-1 in detecting malignant pleural effusions and to establish the extent to which the identification of possible false positives using benign biomarkers (ADA, CRP and PN\%) improves diagnostic accuracy.

\section{Patients and Methods}

From January 2005 to December 2012, pleural effusion fluid samples were collected from consecutive patients of all medical specialties at our hospital who presented pleural effusions.

The reference method was pathological confirmation of cancer in serous pleural effusions, or definitive diagnosis assessed during the three months following the determination of CYFRA 21-1. Serous pleural effusions were defined as malignant when the presence of neoplastic cells was detected by cytology, biopsy or autopsy. Paramalignant pleural effusions were defined as effusions in which no neoplastic cells were detected by any of the methods described above in patients diagnosed with cancer. Diagnostic procedures were performed by assessors who were blinded to the study data.

In order to identify benign pleural effusions, the following tests were performed in fluid and/or serum: protein, albumin, $\mathrm{N}$-terminalpro-brain natriuretic peptide (Nt-ProBNP), lactate dehydrogenase (LDH), microbiological cultures, and if necessary antinuclear antibodies, anti-cyclic citrullinated peptide, rheumatoid factor, thyrotropin, and serological tests for viruses, bacteria and fungi.

Effusion fluid samples were collected and analyzed on the same day. CYFRA21-1 was determined using an electrochemiluminescence method on a Cobas 601 analyzer (Roche Diagnostics, Barcelona, Spain). The analytical variation of CYFRA21-1 expressed as the between-assay coefficient of variation was $3.0 \%$ at concentrations of $3.2 \mathrm{ng} / \mathrm{ml}$.

The criteria used to suggest that an effusion may be a false positive (i.e., empyema, complicated parapneumonic effusion or tuberculosis) were $\mathrm{PN} \%>90, \mathrm{CRP}>5.0 \mathrm{mg} / \mathrm{dl}$ (to convert to milligrams per liter multiply per 10$)$ or $A D A>45 \mathrm{U} / 1(16,17)$. The use of these biomarkers identified two groups of effusions: group A, effusions with all biomarkers below the cut-off point, and group $\mathrm{B}$, effusions with at least one positive biomarker. ADA (EC3 5.4.4) (ITC Diagnostics, Barcelona, Spain) and CRP (Tina-quant CRP latex, Roche Diagnostics, Barcelona, Spain) were determined in a LX-20 autoanalyzer (Beckman Coulter, Madrid, Spain). Leukocyte 
Table II. Diagnostic accuracy of CYFRA 21-1 at $175 \mu \mathrm{g} / \mathrm{l}$ cut-off.

\begin{tabular}{|c|c|c|c|c|c|c|}
\hline & \multicolumn{3}{|c|}{ Whole group } & \multicolumn{3}{|c|}{ Negative cytology } \\
\hline & $\begin{array}{l}\text { All effusions } \\
\quad(\mathrm{n}=643)\end{array}$ & $\begin{array}{l}\text { Group A } \\
(\mathrm{n}=502)\end{array}$ & $\begin{array}{l}\text { Group B } \\
(\mathrm{n}=141)\end{array}$ & $\begin{array}{l}\text { All effusion } \\
(\mathrm{n}=561)\end{array}$ & $\begin{array}{l}\text { Group A } \\
(\mathrm{n}=424)\end{array}$ & $\begin{array}{l}\text { Group B } \\
(n=137)\end{array}$ \\
\hline Prevalence of malignant effusions & $28.9(25.5-32.6)$ & $32.7(28.6-37.0)$ & $15.6(10.2-22.9)$ & $18.6(15.5-22.1)$ & $20.3(16.7-24.6)$ & $13.2(8.4-20.4)$ \\
\hline Sensitivity $(\%)$ & $38.7(31.7-46.1)$ & $39.0(31.6-47.0)$ & $36.4(18.0-59.2)$ & $30.8(22.3-40.7)$ & $29.1(20.0-40.0)$ & $38.9(18.3-63.9)$ \\
\hline Specificity (\%) & $97.3(95.3-98.6)$ & $98.2(96.0-99.3)$ & $95.0(88.9-97.9)$ & $97.4(95.3-98.6)$ & $98.2(96.0-99.3)$ & $95.0(88.9-97.9)$ \\
\hline NPV $(\%)$ & $79.6(76.0-82.8)$ & $76.9(72.5-80.7)$ & $89.0(81.9-97.9)$ & $86.0(82.6-88.8)$ & $84.4(80.4-87.8)$ & $91.1(84.2-95.2)$ \\
\hline PPV (\%) & $85.7(76.0-92.1)$ & $91.4(81.6-96.5)$ & $57.1(29.6-81.2)$ & $72.7(57.0-84.5)$ & $80.7(61.9-91.9)$ & $53.8(26.1-79.6)$ \\
\hline PLR & $14.7(8.2-26.5)$ & $22.0(9.7-49.7)$ & $7.2(2.8-18.8)$ & $11.7(6.2-21.9)$ & $16.3(6.0-38.6)$ & $7.6(2.9-20.2)$ \\
\hline NLR & $0.63(0.56-0.71)$ & $0.62(0.55-0.70)$ & $0.67(0.49-0.92)$ & $0.71(0.62-0.81)$ & $0.72(0.63-0.83)$ & $0.64(0.44-0.93)$ \\
\hline
\end{tabular}

95\%: Confidence interval.

Table III. Sensitivity of CYFRA 21-1 at 100\% specificity and fluid concentrations ( $\mu \mathrm{g} / \mathrm{l})$ in the different groups.

\begin{tabular}{lcccc}
\hline & Cytology (95\%CI) & $\begin{array}{c}\text { Sensitivity at 100\% } \\
\text { specificity (co) }\end{array}$ & $\begin{array}{c}\text { Benign effusions } \\
\text { Median (IQR) }\end{array}$ & $\begin{array}{c}\text { Malignant effusions } \\
\text { Median (IQR) }\end{array}$ \\
\hline All effusions (n=643) & $44.1 \%(36.9-51.5)$ & $22.6 \% 42 / 186(447)$ & $13.2(23.5)^{\mathrm{a}}$ & $92.6(354.6)$ \\
Group A (n=502) & $47.6 \%(39.8-55.5)$ & $25.6 \% 42 / 164(324)$ & $11.4(19.9)^{\mathrm{a}}$ & $96.7(299.9)$ \\
Group B (n=141) & $18.2 \%(6-41)$ & $36.4 \% 8 / 22(447)$ & $22.4(39.5)^{\mathrm{a}, \mathrm{b}}$ & $58.2(1053.9)$ \\
Using specific cut-off & & $26.9 \% 50 / 186$ & - & - \\
\hline
\end{tabular}

95\% CI: 95\% Confidence interval; IQR: interquartile range; co: Cut-off; asignificant difference ( $p=0.001)$ between benign and malignant effusions; bsignificant difference $(p=0.001)$ between benign effusions from groups A and B.

count was performed in a Neubauer chamber using May-GrünwaldGiemsa stain. The analytical variation, expressed as the betweenassay coefficient of variation, was $7.4 \%$ for ADA and $2.3 \%$ for CRP at concentrations of $10.3 \mathrm{U} / 1$ and $7.66 \mathrm{mg} / \mathrm{dl}$ respectively.

Statistical analysis. We used the cut-off of $175 \mu \mathrm{g} / \mathrm{l}$ for CYFRA211 as described previously by Porcel et al. (7) and by our group in pleural effusions and ascites (13). ROC analysis was used to establish a cut-off for CYFRA21-1 at a specificity of $100 \%$. Sensitivity, specificity, negative predictive values (NPV), positive predictive values (PPV), negative likelihood ratio (NLR) and positive likelihood ratio (PLR) were calculated for CYFRA21-1. The parameters of diagnostic accuracy are shown together with their 95\% confidence intervals (CI). A two-sided 5\% significance level was assumed. All statistical analyses were performed using IBM $^{\mathbb{R}}$ SPSS ${ }^{\circledR}$ Statistics for Windows v.22 (IBM Corporation, Armonk, NY, USA) and Stata ${ }^{\circledR}$ V.14 (StataCorp LP, College Station, TX, USA).

\section{Results}

Six hundred forty-three consecutive pleural effusions were included, 253 from women (39.3\%) and 390 from men (60.7\%), with ages ranging from 11 to 97 years (mean=71.6; $\mathrm{SD}=14.8$ ). Table I shows the patients' characteristics. The effusions were classified into two groups: group A (78.1\%), effusions with all benign biomarkers (ADA, CRP and \%PN) below the proposed cut-off point, and group B (21.9\%) effusions with at least one of the benign biomarkers above the cut-off.

Table II shows the diagnostic accuracy of CYFRA 21-1 for the whole group and for group A and group B. For a cut-off of $175 \mu \mathrm{g} / \mathrm{l}$ in group $\mathrm{A}$, six false positives $(6 / 502 ; 1.2 \%)$ were found: two parapneumonic effusions, two paramalignant effusions, one asbestosis, and one non-affiliated effusion. In group B, there were 6/141 (4.2\%) false positives: four empyema, one complicated parapneumonic effusion, and one paramalignant effusion. Figure 1 shows the ROC analysis for whole group, group A and group B. Table III shows the sensitivity of cytology, the diagnostic performance of CYFRA $21-1$ at $100 \%$ specificity and the concentrations of CYFRA 21-1 in the different groups of pleural effusions.

Table IV shows the sensitivity of CYFRA21-1 according to tumor type.

\section{Discussion}

The data reported for sensitivity and specificity using $175 \mu \mathrm{g} / \mathrm{l}$ as a cut-off point for CYFRA21-1 is in concordance with Porcel et al. (7) who found $35 \%$ sensitivity at maximum specificity. Using $150 \mu \mathrm{g} / \mathrm{l}$ as cut-off point, Ferrer et al. (11) obtained a sensitivity of $22.6 \%$. With the same cut-off value, 

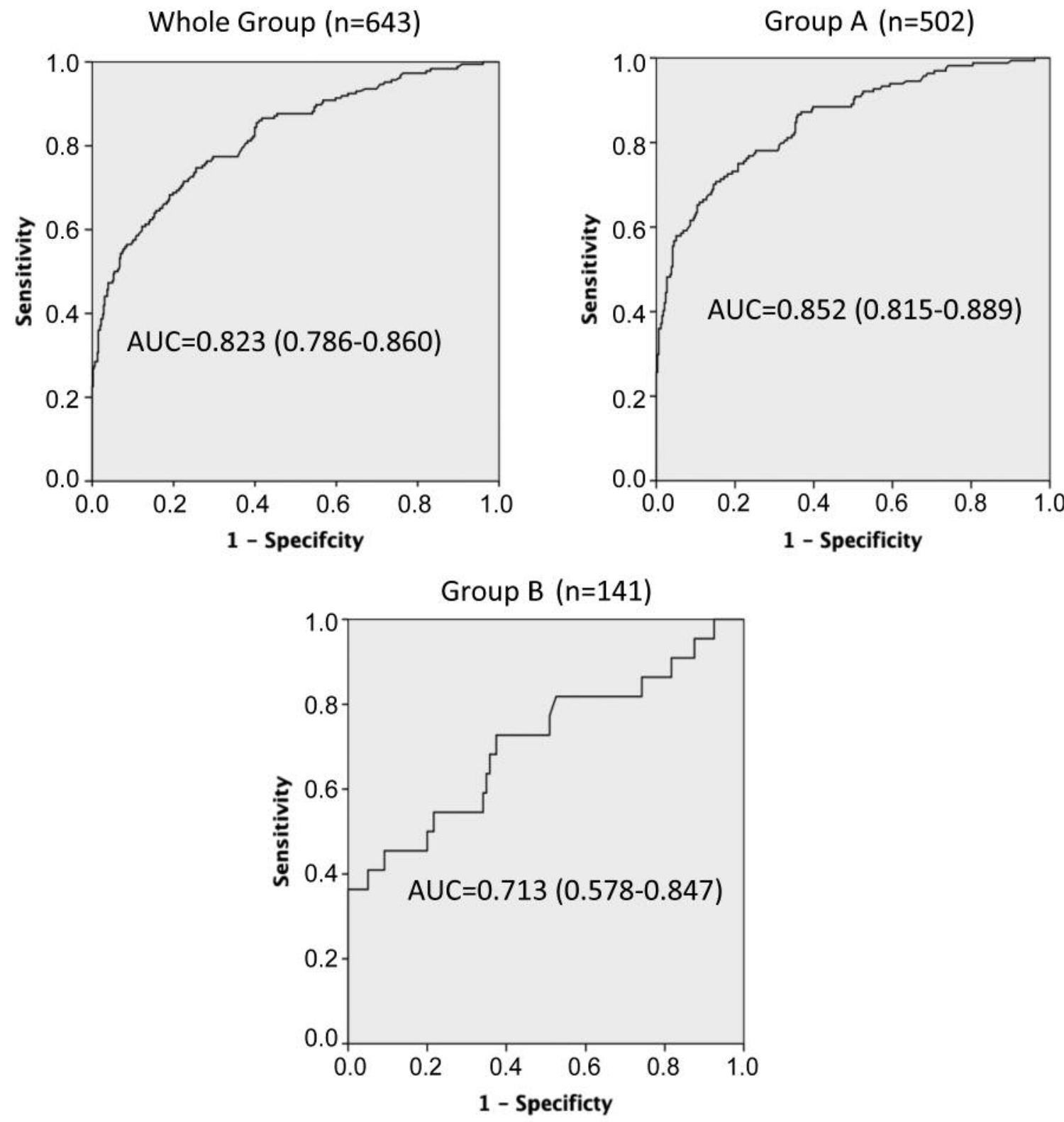

Figure 1. ROC for CYFRA21-1 in different groups of study.

Table IV. Sensitivity and concentrations of CYFRA 21.1 according to tumor type.

\section{\% CYFRA 21-1>175 $\mu \mathrm{g} / 1$}

Lung cancer

Breast cancer

Ovarian cancer

Digestive (pancreas, stomach, colon)

Cancer of unknown primary site

Mesothelioma

Lymphoma, sarcoma, hypernephroma

IQR: Interquartile range.
Mean; Median (IQR) $\mu \mathrm{g} / 1$

$550 ; 140(360.6)$

$322 ; 136(365.8)$

839; 207 (523.3)

$578 ; 40(1623)$

$427 ; 126(368.8)$

$1062 ; 54(893.1)$

$11 ; 7(13.1)$ 
our group (13) obtained $50 \%$ sensitivity at maximum specificity in pleural and ascitic effusions, and in our 2015 study, using the same cut-off, we reported sensitivity and specificity of $50 \%$ and $97.6 \%$ in ascitic effusions (18). With a cut-off point of $163 \mu \mathrm{g} / \mathrm{l}$, Miédougé et al. (12) have reported $42.8 \%$ sensitivity at $99 \%$ specificity. The majority of authors that use cut-offs above $100 \mu \mathrm{g} / \mathrm{l}$ have found sensitivities between $2 \%$ and $50 \%$ at a specificity of more than $95 \%$; other authors who have used cut-offs below $100 \mu \mathrm{g} / \mathrm{l}$ obtained higher sensitivity, but specificity fell below $90 \%(7,9,19,20)$. The current study showed that non-malignant effusions with benign positive biomarkers have higher concentrations of CYFRA211 than non-malignant effusions with negative benign biomarkers. These results are similar to those obtained previously by our group for CEA, CA15-3, CA19-9 and CA724 , where the majority of false positive cases were included (16). In group B, the prevalence of empyema, complicated parapneumonic and tuberculous effusions was approximately $50 \%$, but the figure did not reach $2 \%$ in group A. This strategy, used previously by our group for other tumor markers, enabled us to identify most of the false positives in the group with positive benign biomarkers. This seems to be a valid way to improve the sensitivity of tumor markers in effusion fluid; the group with benign biomarkers has low prevalence of malignancy and a high prevalence of false positives.

Most of the tumors shown to have increased CYFRA21-1 were epithelial cancers. Increased CYFRA21-1 was found in $44.7 \%$ of lung cancers, $60 \%$ of ovarian cancers, and $37.5 \%$ of breast cancers, and among non-epithelial tumors it was recorded in $31.8 \%$ of mesotheliomas and in one multiple myeloma.

The differences between NPV, PPV and PLR in groups A and B should be noted. In group A, PPV was above $90 \%$ and PLR+ above 20 , indicating that the impact on post-test probability is large; in group B, this impact was only moderate.

In conclusion, the determination of CYFRA 21-1 in pleural effusion shows a high specificity but moderate sensitivity. With our subclassification into two groups, diagnostic performance increased in the group with negative benign biomarkers, and was poorer in the group with at least one positive benign biomarker. These results indicate that CYFRA 21-1 is most effective in effusions with negative benign biomarkers.

\section{Conflicts of Interest}

The Authors declare that they have no conflicts of interests regarding this study.

\section{Authors' Contributions}

Conception and design: JT, RM; Analysis and interpretation: JT, JM, AA, MS, JL, CG; Histological examination FS; Acquisition data: OB, EM DP, SR, EE, RP, JA, SC, MD, DR, MB, JO; Critical revisions: All Authors. All Authors read and approved the final manuscript.

\section{Acknowledgments}

The Authors thank Michael Maudsley for his help with the translation and editing of the manuscript.

\section{References}

1 Light RW: Pleural Diseases, 6th ed, Philadelphia: Lippincott Williams \& Wilkins, 2013.

2 Porcel JM, Esquerda A, Vives M and Bielsa S: Etiology of pleural effusions: analysis of more than 3,000 consecutive thoracenteses. Arch Bronconeumol 50(5): 161-165, 2014. PMID: 24360987. DOI: 10.1016/j.arbres.2013.11.007

3 Alemán C, Sanchez L, Alegre J, Ruiz E, Vázquez A, Soriano T, Sarrapio J, Teixidor J, Andreu J, Felip E, Armadans L and Fernández De Sevilla T: Differentiating between malignant and idiopathic pleural effusions: the value of diagnostic procedures. QJM 100(6): 351-359, 2007. PMID: 17525131.

4 Gu P, Huang G, Chen Y, Zhu C, Yuan J and Sheng S: Diagnostic utility of pleural fluid carcinoembryonic antigen and CYFRA 211 in patients with pleural effusion: a systematic review and meta-analysis. J Clin Lab Anal 21(6): 398-405, 2007. PMID: 18022924.

5 Volarić D, Flego V, Žauhar G and Bulat-Kardum L: Diagnostic value of tumour markers in pleural effusions. Biochem Med (Zagreb) 28(1): 010706, 2018. PMID: 29472801. DOI: 10.11613/ BM.2018.010706

6 Sharma SK, Bhat S, Chandel V, Sharma M, Sharma P, Gupta S, Sharma S and Bhat AA: Diagnostic utility of serum and pleural fluid carcinoembryonic antigen, and cytokeratin 19 fragments in patients with effusion from nonsmall cell lung cancer. J Carcinog 14: 7, 2015. PMID: 26900349. DOI: 10.4103/1477-3163.170662

7 Porcel JM, Vives M, Esquerda A, Salud A, Pérez B and Rodríguez-Panadero F: Use of a panel of tumor markers (carcinoembryonic antigen, cancer antigen 125, carbohydrate antigen 15-3, and cytokeratin 19 fragments) in pleural fluid for the differential diagnosis of benign and malignant effusions. Chest 126(6): 1757-1763, 2004. PMID: 15596670.

8 Feng M, Zhu J, Liang L, Zeng N, Wu Y, Wan C, Shen Y and Wen F: Diagnostic value of tumor markers for lung adenocarcinoma-associated malignant pleural effusion: a validation study and meta-analysis. Int J Clin Oncol 22(2): 283290, 2017. PMID: 27990560. DOI: 10.1007/s10147-016-1073-y

9 Cynowska B, Słomiński JM, Goszka LW, Andrzejewski W and Wolf H: Value of determination of lung cancer marker Cyfra 211 for differentiation of pleural fluid - preliminary report. Med Sci Monit 4: 934-937, 1998.

10 Salama G, Miédougé M, Rouzaud P, Mauduyt MA, Pujazon MC, Vincent C, Carles P and Serre G: Evaluation of pleural CYFRA 21-1 and carcinoembryonic antigen in the diagnosis of malignant pleural effusions. Br J Cancer 77(3): 472-476, 1998. PMID: 9472646.

11 Ferrer J, Villarino MA, Encabo G, Felip E, Bermejo B, Vilà S and Orriols R: Diagnostic utility of CYFRA 21-1, carcinoembryonic antigen, CA 125, neuron specific enolase, and squamous cell antigen level determinations in the serum and pleural fluid of patients with pleural effusions. Cancer 86(8): 1488-1495, 1999. PMID: 10526277. 
12 Miédougé M, Rouzaud P, Salama G, Pujazon MC, Vincent C, Mauduyt MA, Reyre J, Carles P and Serre G: Evaluation of seven tumour markers in pleural fluid for the diagnosis of malignant effusions. Br J Cancer 81(6): 1059-1065, 1999. PMID: 10576665.

13 Trapé J, Molina R and Sant F: Clinical evaluation of the simultaneous determination of tumor markers in fluid and serum and their ratio in the differential diagnosis of serous effusions. Tumour Biol 25(5-6): 276-281, 2004. PMID: 15627892.

14 Valdés L, San-José E, Ferreiro L, González-Barcala FJ, Golpe A, Álvarez-Dobaño JM, Toubes ME, Rodríguez-Núñez N, Rábade C, Lama A and Gude F: Combining clinical and analytical parameters improves prediction of malignant pleural effusion. Lung 191(6): 633-643, 2013. PMID: 24085319. DOI: 10.1007/s00408-013-9512-2

15 Barillo JL, da Silva Junior CT, Silva PS, de Souza JBS, Kanaan S, Xavier AR and de Araujo EG: Increased cytokeratin 19 fragment levels are positively correlated with adenosine deaminase activity in malignant pleural effusions from adenocarcinomas. Dis Markers 2018: 2609767, 2018. PMID: 29854023. DOI: $10.1155 / 2018 / 2609767$

16 Trapé J, Sant F, Franquesa J, Montesinos J, Arnau A, Sala M, Bernadich O, Martín E, Perich D, Pérez C, Lopez J, Ros S, Esteve E, Pérez R, Aligué J, Gurt G, Catot S, Domenech M, Bosch J, Badal JM, Bonet $\mathrm{M}$, Molina $\mathrm{R}$ and Ordeig $\mathrm{J}$ : Evaluation of two strategies for the interpretation of tumour markers in pleural effusions. Respir Res 18(1): 103, 2017. PMID: 28545517. DOI: 10.1186/s12931-017-0582-1
17 Trapé J, Molina R, Sant F, Montesinos J, Arnau A, Franquesa J, Blavia R, Martín E, Marquilles E, Perich D, Pérez C, Roca JM, Doménech M, López J and Badal JM: Diagnostic accuracy of tumour markers in serous effusions: a validation study. Tumour Biol 33(5): 1661-1668, 2012. PMID: 22678976. DOI: 10.1007/ s13277-012-0422-3

18 Trapé J, Gurt G, Franquesa J, Montesinos J, Arnau A, Sala M, Sant F, Casado E, Ordeig JM, Bergos C, Vida F, Sort P, Isava Á, González M and Molina R: Diagnostic accuracy of tumor markers CYFRA21-1 and CA125 in the differential diagnosis of ascites. Anticancer Res 35(10): 5655-5660, 2015. PMID: 26408739.

19 Chen M, Xie S, Wan C, Zeng N, Wu Y, Qin J, Shen Y and Wen F: Diagnostic performance of CTLA-4, carcinoembryonic antigen and CYFRA 21-1 for malignant pleural effusion. Postgrad Med 129(6): 644-648, 2017. PMID: 28506100. DOI: 10.1080/00325481.2017.1331112

20 Antonangelo L, Sales RK, Corá AP, Acencio MM, Teixeira LR and Vargas FS: Pleural fluid tumour markers in malignant pleural effusion with inconclusive cytologic results. Curr Oncol 22(5): e336-341, 2015. PMID: 26628873. DOI: $10.3747 /$ co. 22.2563

Received July 7, 2019

Revised July 11, 2019

Accepted July 12, 2019 